\title{
EMOTIONAL INTELLIGENCE AMONG LITHUANIAN AND LATVIAN STUDENT ATHLETES
}

\author{
Romualdas Malinauskas, Zermena Vazne \\ Lithuanian Sports University, Kaunas, Lithuania \\ Latvian Academy of Sport Education, Riga, Latvia
}

\begin{abstract}
Background. This article deals with the issue of the manifestation of emotional intelligence in Lithuanian and Latvian student athletes. Emotional intelligence has been suggested as providing a new perspective on how emotional competencies necessary for performance in today's workplace among would-be physical educators might be more effective and better understood. Hence, the following research question is raised: does the emotional intelligence of Lithuanian student athletes differ from that of Latvian student athletes? We hypothesized that the emotional intelligence of Lithuanian student athletes differs from that of Latvian student athletes. Research aim was to reveal the manifestation of emotional intelligence in Lithuanian and Latvian student athletes.

Methods. The independent random sample consisted of 227 student athletes from the Latvian Academy of Sports Education and 214 student athletes from the Lithuanian Sports University. Schutte Self-Report Inventory (SSRI) was employed. This instrument divides emotional intelligence into four separate components, namely: ability to use personal positive emotional experience (optimism), ability to assess and express emotions (appraisal), ability to understand and analyse emotions (social skills) and ability to manage emotions (utilization).

Results. The analysis of the ability to use personal positive emotional experience resulted in the following averages: $51.48 \pm 5.24$ in case of the Lithuanian student athletes and $52.78 \pm 6.33$ in case of the Latvian student athletes. The application of the Student's t-test revealed a statistically significant difference in the ability of the Lithuanian student athletes to use own positive emotional experience and that of the Latvian student athletes: $\mathrm{t}(439)=2.32 ; \mathrm{p}<.005$.

Conclusions. The comparison of the components of emotional intelligence of Lithuanian and Latvian student athletes revealed that Latvian student athletes have better ability to use own positive emotional experience (optimism) $(p<.05)$. No other statistically significant difference between Lithuanian and Latvian student athletes in terms of the components of emotional intelligence was observed.
\end{abstract}

Keywords: emotional intelligence, emotions, student athletes.

\section{INTRODUCTION}

$\mathrm{T}$ The significance of emotional intelligence for educators is a subject of continuous scientific discussions. The emergence of the emotional intelligence term received a great deal of attention from the scientists and inspired a number of articles. It is a proven fact that the "emotionally gifted" people have inner advantage both in terms of personal and professional life, and therefore they are happier and more successful. It was even suggested that it is the emotional intelligence rather than IQ or cognitive abilities that matters more when predicting and assessing academic and professional achievement (Goleman, 1995). We believe that it is crucially important to observe and analyse the segment of would-be teachers because the currently available educational programs that are designed to develop the emotional intelligence of the students of Education Studies are insufficient.

Mayer and Salovey (1993) developed an ability model of emotional intelligence which emphasized 
the importance of the components of emotional intelligence. This model defines emotional intelligence as abilities (Matthews, Zeidner, \& Roberts, 2003). The model reveals that emotional intelligence as construct is lot like traditional intelligence because the abilities associated with emotional intelligence also alter with age (Mayer, Salovey, \& Caruso, 2000). Although Salovey and Mayer (1990) initially described emotional intelligence as a single personality trait, eventually they claimed that emotional intelligence should be perceived as the totality of a person's abilities (Mayer et al., 2000). Mayer et al. (2000) interpret emotional intelligence as the abilities which help to express and manage emotions during social interactions. The Mayer-Salovey-Caruso model (2000) is multifold because emotional intelligence is perceived as the totality of components and abilities. The perception, assessment and expression of emotions are described as processes whereas the control of emotions is the most important of the processes (Mayer et al., 2000).

The earlier research carried out by Malinauskas and Malinauskiene (2004) suggests that the continuous professional development of wouldbe sports educators (in our case Lithuanian and Latvian student athletes) is becoming an increasingly more significant factor determining successful development of the entire educational system, whereas emotional intelligence now plays a critically important role in the professional life of would-be sports educators. The earlier research reveals that the would-be sports educators who are female are more empathic than their male counterparts (Malinauskas \& Malinauskienè, 2004). However, this problematic area has not been sufficiently researched on the intercultural level and the emotional intelligence manifested by Lithuanian and Latvian student athletes has not been thoroughly revealed because the research was limited to observation of Lithuanian and Latvian school students during their physical education classes (Akelaitis \& Malinauskas, 2013).

Hence, the following research question is raised: does the emotional intelligence of Lithuanian student athletes differ from that of Latvian student athletes?

Scientific novelty: the present research will provide the first thorough analysis of the components of the emotional intelligence of Lithuanian and Latvian student athletes.
The object of the research is the emotional intelligence of Lithuanian and Latvian student athletes.

The aim of the research is to reveal the manifestation of emotional intelligence in Lithuanian and Latvian student athletes.

Hypothesis of the research: we hypothesize that the emotional intelligence of Lithuanian student athletes differs from that of Latvian student athletes.

\section{METHODS}

Instruments: data collection and analysis. Schutte Self-Report Inventory (SSRI) was employed. This instrument is extremely beneficial in the way that it divides emotional intelligence into four separate components (Palmer, 2003), namely: ability to use personal positive emotional experience (optimism), ability to assess and express emotions (appraisal), ability to understand and analyse emotions (social skills) and ability to manage emotions (utilization). The questionnaire was designed to facilitate the measurement of the respondents' ability to identify, understand, utilize and independently manage emotions in both themselves and others (Schutte et al., 1998; Schutte \& Malouff, 1999).

The internal consistency of the questionnaire employed in the research was measured with Cronbach's alpha. The value of the Cronbach's alpha coefficient for the research sample was .76. The statistical hypotheses were tested with Student's t-test because the data followed normal distribution. The Lithuanian version of the SSRI shows internal consistency value .79 and a testretest reliability coefficient of .84 for the overall questionnaire (Malinauskas \& Šniras, 2010). The Latvian version of the SSRI shows internal consistency value .78 (Akelaitis \& Malinauskas, 2013).

Sample and procedure. The research was carried out during the 2013/2014 academic year. The independent random sample consisted of 227 student athletes from the Latvian Academy of Sports Education and 214 student athletes from the Lithuanian Sports University. The respondents were distributed from the $1^{\text {st }}$ to the $4^{\text {th }}$ academic year and all were studying in the bachelor degree program of physical education. The gender distribution in the research sample was as follows: 299 respondents were male and 142 respondents were female. 
A two-level sampling strategy was applied. First of all, the groups of students were selected from random tables, and then all the students from the selected groups were researched. The research covered all the students from the $1^{\text {st }}$ to the $4^{\text {th }}$ academic year who were enrolled in the study programs titled Sport Coaching and Physical Education. The survey was conducted in compliance with the ethical principles and applicable legislation, i. e. each respondent was explained the goal of the study and was ensured that the questionnaires were anonymous. The survey was conducted during the internship practice of Education Studies. The duration of the survey was 20 minutes.

\section{RESULTS}

The gender issue was not taken into consideration in the present research because the major goal was to reveal intercultural differences between the Lithuanian and Latvian student athletes in terms of emotional intelligence. The research started from the analysis of the ability of the Lithuanian and Latvian student athletes to use personal positive emotional experience (optimism). The analysis of the ability to use personal positive emotional experience resulted in the following mean scores: $51.48 \pm 5.24$ for Lithuanian student athletes and $52.78 \pm 6.33$ for Latvian student athletes (Figure 1).

The application of the Student's t test revealed a statistically significant difference in the ability of the Lithuanian student athletes to use their own positive emotional experience and that of the Latvian student athletes: $\mathrm{t}(439)=2.32 ; \mathrm{p}<.05$.

Having recalculated the indicator averages into points, it was determined that, with an exception of the ability of Lithuanian and Latvian student athletes to understand and analyse emotions

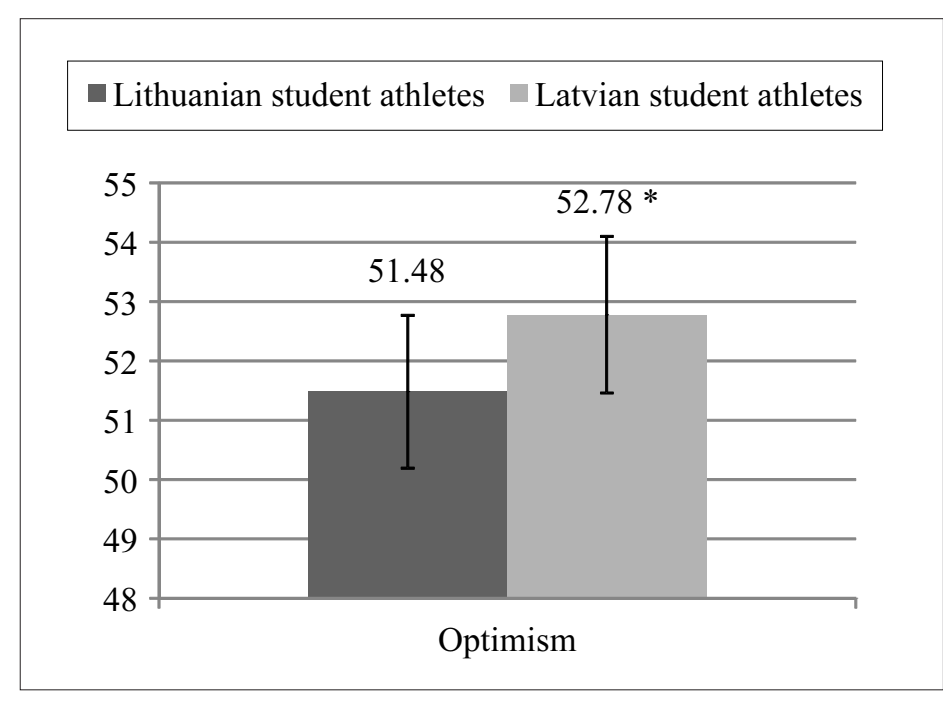

- Lithuanian student athletes $\quad$ Latvian student athletes

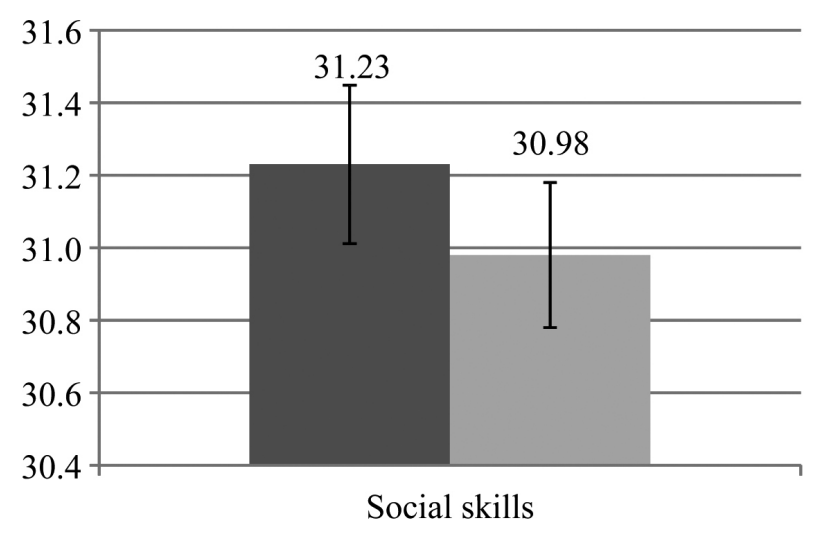

Figure 1. Mean scores of the ability of the Lithuanian and Latvian student athletes to use personal positive emotional experience (optimism)

Note. $*-p<.05-$ there is a statistically significant difference between the results of Lithuanian and Latvian student athletes.

Figure 2. Mean scores of the ability of the Lithuanian and Latvian student athletes to understand and analyse emotions (social skills)

Note. $p>.05$. 
Table. The statistical indicators of the abilities of emotional intelligence among Lithuanian and Latvian student athletes $(\mathbf{M} \pm \mathbf{S D})$

Note. $\mathrm{M}=$ mean; $\mathrm{SD}=$ standard deviation.

\begin{tabular}{|l|c|c|c|}
\hline \multicolumn{1}{|c|}{$\begin{array}{c}\text { Abilities of emotional } \\
\text { intelligence }\end{array}$} & $\begin{array}{c}\text { Lithuanian } \\
\text { student athletes } \\
(\mathbf{n}=\mathbf{2 1 4})\end{array}$ & $\begin{array}{c}\text { Latvian student } \\
\text { athletes } \\
(\mathbf{n}=\mathbf{2 2 7})\end{array}$ & $\mathbf{t} ; \mathbf{p}$ \\
\hline $\begin{array}{l}\text { Ability to assess and express } \\
\text { emotions (appraisal) }\end{array}$ & $21.81 \pm 2.85$ & $21.55 \pm 3.31$ & $\begin{array}{c}-0.87 \\
\mathrm{p}>.05\end{array}$ \\
\hline $\begin{array}{l}\text { Ability to manage emotions } \\
\text { (utilization) }\end{array}$ & $16.14 \pm 2.70$ & $16.42 \pm 3.19$ & 1.00 \\
\cline { 3 - 4 } & & $\mathrm{p}>.05$ \\
\hline
\end{tabular}

(social skills), there was no statistically significant difference between the Lithuanian and the Latvian student athletes ( $(439)=-0.61 ; p>.05$; Figure 2).

The research also addressed the ability of Lithuanian and Latvian student athletes to assess and express emotions (appraisal of emotions). It was determined that the Lithuanian and Latvian student athletes were similar in terms of the ability to assess and express their emotions (Table).

The research results revealed that there were no significant differences between the Lithuanian and Latvian student athletes in terms of their ability to assess and express emotions (utilization) $(\mathrm{t}(439)=-0.87 ; \mathrm{p}>.05)$. The data set out in Table shows that the Lithuanian and Latvian student athletes are not different in terms of the ability to manage their emotions $(\mathrm{t}(439)=1.00 ; \mathrm{p}>.05)$.

\section{DISCUSSION}

The carried out research helped assess the intensity of the components of emotional intelligence in the Lithuanian and Latvian student athletes. The reliability of the data of this research can be validated both by the results announced by Gaitniece-Putāne (2008) and by the results obtained from our Latvian sample because Gaitniece-Putāne (2008) obtained similar results when researching her Latvian respondents of the same age.

The results of this research also do not contradict with the results obtained in the earlier research involving Lithuanian and Latvian school students because the higher education students were different only in terms of a single component of emotional intelligence, whereas the school students did not differ at all. The results of this research also compliment other studies claiming that intercultural differences in the Eastern European countries in terms of abilities (components) of emotional intelligence are insignificant (Bakacsi, Takacs, Karacsonvi, \& Imrek, 2002) because all these countries belong to a single cluster.
However, all previous researchers of emotional intelligence worked with managers rather than student athletes. The results of the present study revealed that intercultural differences did influence one of the abilities of emotional intelligence, i. e. the ability to use personal positive emotional experience (optimism). The fact that the Latvian student athletes demonstrated better ability to use personal positive emotional experience (optimism) may be explained by the Winter Olympic Games prior to which the present research was conducted and during which Latvian athletes achieved better results. Moreover, more Latvian student athletes participated in the Winter Olympic Games in Sochi.

Our study was focused on the student athletes, i. e. would-be sports educators, whereas Murphy (2006) researched the students majoring in social science, management and technical subjects. We found out that the Latvian student athletes demonstrated better ability to use personal positive emotional experience (optimism), whereas Murphy (2006) did not look for intercultural differences but determined that the female respondents had better ability to understand and analyse emotions that the male respondents in that particular research. Since we did not compare our research results in terms of gender, we believe that such analysis could be carried out in future studies.

Summing up, it may be stated that the research methods employed in the study carried out with the Lithuanian and Latvian student athletes could also be efficiently used to research the students from the same countries who are enrolled in different study programs. It would be useful to continue the study in this particular field by focusing on the differences of emotional intelligence in terms of different gender and different age (different year of study). The study could be further developed by looking for differences between Lithuanian and Latvian student athletes and graduate student athletes working as physical education and sports specialists in terms of their emotional intelligence. 


\section{CONCLUSION}

The comparison of the components of emotional intelligence of Lithuanian and Latvian student athletes revealed that Latvian student athletes had better ability to use personal positive emotional experience (optimism) $(\mathrm{p}<.05)$. No other significant difference between Lithuanian and Latvian student athletes in terms of the components of emotional intelligence was observed.

\section{REFERENCES}

Akelaitis, A., \& Malinauskas, R. (2013). Emotional intelligence among Lithuanian and Latvian students of senior high school age in physical education classes. 6th Baltic Scientific Conference "Sport Science for Sustainable Society“ (p. 34). Riga: Latvian Academy of Sport Education.

Bakacsi, G., Takacs, S., Karacsonvi, A., \& Imrek, V. (2002). Eastern European Cluster: Tradition and transition. Journal of World Business, 37(1), 69-80.

Gaitniece-Putāne, A. (2008). Agresijas, emocionālā intelekta un stoicisma saistiba 20-25 un 30-35 gadus veciem viriešiem unsievietem: promocijas darbs. Rīga: Latvijas universitāte.

Goleman, D. (1995). Emotional intelligence. New York: Bantam Books.

Malinauskas, R., \& Malinauskiené, V. (2004). Socialinio rengimo poveikis sporto pedagogu empatijai. Acta Paedagogica Vilnensia, 13, 162-168.

Malinauskas, R., \& Šniras, Š. (2010). Būsimujų kūno kultūros mokytojų emocinès inteligencijos raiška. Mokslas ir edukaciniai procesai, 4(13), 81-88.

Matthews, G., Zeidner, M., \& Roberts, R. D. (2003). Emotional intelligence: Science and myth. Cambridge: MIT Press.

Mayer, J. D., Salovey, P., \& Caruso, D. R. (2000). Selecting a measure of emotional intelligence. In R. BarOn, J. D. \& Parker (Eds.), The handbook of emotional intelligence: Theory, development, assessment, and application at home, school, and in the workplace (pp. 320-342). San Francisco: Jossey-Bass Inc.

Mayer, J. D., \& Salovey, P. (1993). The intelligence of emotional intelligence. Intelligence, 77(4), 433-442.

Murphy, A. (2006). A comparison of the emotional intelligence and thinking styles of students in different university study fields: doctoral thesis. Johannesburg: University of South Africa.

Palmer, B. R. (2003). An analysis of the relationship between various models and measures of emotional intelligence: doctoral dissertation. Melbourne: Swinburne University of Technology.

Salovey, P., \& Mayer, J. D. (1990). Emotional Intelligence. Imagination, Cognition and Personality, 9, 158-221.

Schutte, N. S., Malouff, J. M., Hall, L. E., Haggerty, D. J., Cooper, J. T., Golden, C. J., \& Dornheim, L. (1998). Development and validation of a measure of emotional intelligence. Personality and Individual Differences, 25, 167-177.

Schutte, N. S., \& Malouff, J. M. (1999). Measuring emotional intelligence and related constructs. New York: Edwin Mellen Press.

Tok, S., \& Morali, S. L. (2009). Trait emotional intelligence, the Big five personality dimensions and academic success in physical education teacher candidates. Social Behaviour and Personality, 37(7), 921-932. 